\title{
The Effect of Socioeconomic Status on Parents' Dialogicality
}

\author{
Özge Cengiz \\ Department of Foreign Language Education, İstanbul Medeniyet University, İstanbul, Turkey \\ Email: ozge.cengiz@medeniyet.edu.tr
}

Received 31 March 2016; accepted 19 April 2016; published 22 April 2016

Copyright (C 2016 by author and Scientific Research Publishing Inc.

This work is licensed under the Creative Commons Attribution International License (CC BY).

http://creativecommons.org/licenses/by/4.0/

(c) $\underset{\mathrm{EY}}{\mathrm{i}}$ Open Access

\section{Abstract}

Parent level of education makes important contributions to the linguistic development of children (Hoff, 2003). This cross-sectional study, focusing on the link between families' socioeconomic status (SES) and their language use, aims to investigate whether parents' levels of SES influence their interaction styles with their children in terms of dialogicality. Dialogicality refers to "the ways in which one speaker's concrete utterances come into contact with the utterances of another" (Wertsch, 1991: p. 54). Research suggests that when adults give children opportunities of dialogicality and let them become active participants during conversations, i.e. when the interactions are more dialogic, children show greater language gains (Whitehurst \& Lonigan, 1998). Within this context, this study is an attempt to explore how and to what extent parents from different socioeconomic backgrounds encourage their preschoolers to become more active in their interactions. Ten families differing in SES were audio-taped in their homes for about 15 minutes in the toy play context with their five-year-old children. The transcriptions were coded as exchanges, and then each exchange was coded as an II or IR or IRF pattern according to Sinclair \& Coulthard's spoken discourse model which was developed in 1975. The model, consisting of three-part exchanges: Initiation, Response, and Feedback, known as IRF, was developed through the application of transcripts taken from primary school classroom settings in the 1970's. Focusing on these parentpreschooler dialogues, this study tried to find out whether families' interaction styles differentiate depending on their SES; thus, which children were encouraged more to become active speakers before starting their formal education. The results show that SES has a crucial effect upon parents' dialogicality, that is, high SES parents' interaction styles are much more dialogic.

\section{Keywords}

Dialogicality, Dialogic Discourse, Monologic Discourse, Child-Directed Speech, IRF Model 


\section{Introduction}

Over the last few decades there has been growing interest in research on parents and their involvement in children's lives. Research has shown that parents' engagement with their children is related to children's linguistic and cognitive skills (e.g. Tamis-LeMonda, Shannon, Cabrera, \& Lamb, 2004). Research on language input to children and parent-child interactions have mostly focused on motherese, that is, maternal language use. Studies on paternal language have been very limited. However, recent studies on paternal language have shown that fathers also contribute to their children's language development (e.g. Tamis-LeMonda, Shannon, Cabrera, \& Lamb, 2004; Duursma, Pan, \& Raikes, 2008; Pancsofar \& Vernon-Feagans, 2006, 2010; Pancsofar et al., 2013; Duursma, 2014).

Research also documents that family socioeconomic status (SES) is a powerful predictor of many aspects of child development (Hoff, 2003), especially linguistic development. It is well established that children from lower SES build their vocabularies at slower rates than children from higher SES. More educated and advantaged parents have children with greater vocabulary skills and faster vocabulary growth during early childhood than less educated and advantaged parents. Further research has shown that this relation between SES and child vocabulary skill is due, in part, to the speech that parents offer children during day-to-day interactions (Hoff, 2003; Rowe, 2008). Studies focusing on SES and language development in children (Hart \& Risley; 1995; Hoff, 2003, 2006; Cabrera, Shannon, \& Tamis-LeMonda, 2007; Duursma, Pan, \& Raikes, 2008; Rowe, 2008) found differences related to socioeconomic backgrounds of the families. Hoff-Ginsberg (1998) observed that child-directed speech in high SES families contained richer vocabulary of object labels. Especially high SES mothers prefered longer utterances and a variety of words. Thus, since high SES children had access to different words, they possesed larger vocabularies. Low SES mothers, on the other hand, talked less and used less varied vocabulary during child-directed speech. Heath (1983) and Ninio (1980) also found that parents from low SES talk much less to their children than high SES parents. According to Hoff, Laursen \& Tardif (2002), maternal language input to children changes in accordance with family SES. High SES mothers support child language development. McCabe \& Peterson (1991) and Peterson \& McCabe (1992) point out that maternal and paternal language input to young children have an impact on children's later narrative styles. Studies on shared book reading found that parents who have a better education demonstrate better literacy skills. Thus, these studies showed that parents' socioeconomic backgrounds have an impact on the emergent literacy skills of their children (Raikes et al., 2006; Duursma, Pan, \& Raikes, 2008; Duursma, 2014).

Studies focusing on maternal and paternal language (Fernald, Taeschner, Dunn, \& Papousek, 1989; Kavanaugh \& Jirkovsky, 1982; Rondal, 1980; McRoberts \& Best, 1997; Leaper, Anderson, \& Sanders, 1998; Pancsofar \& Vernon-feagans, 2006, 2010) have found similarities as well as differences between parents' childdirected speech. Golinkoff \& Ames (1979) compared maternal and paternal language in a dyadic and triadic situation and found that in the dyadic situation, mothers and fathers produced similar number of utterances but in the triadic situation, the fathers produced fewer utterances than mothers. Fernald, Taeschner, Dunn \& Papousek, (1989) compared mother and father verbal input and they found that fathers adopted a simplified speech register and spoke with a higher pitch. Studies examining language input in the context of book reading suggest that maternal as well as paternal book reading can help children’s language development (Raikes et al., 2006; Duursma, Pan, \& Raikes, 2008). There are some other studies in which differences between parents on measures of total output have not been observed (McLaughlin, White, McDevitt, \& Raskin, 1983; Hladik \& Edwards, 1984; O’Brien \& Nagle, 1987).

This cross-sectional study, focusing on the link between families' SES and their language use, aims to investigate whether parents' SES, i.e. education and income, influence their interaction styles with their children in terms of dialogicality. Several studies on parent-child interaction investigated language input of either mothers or fathers in contexts such as book-reading, picture task, meal time and dressing. This study investigates the properties of both maternal and paternal language input by examining the interaction between parents and their preschoolers in the context of toy play with regard to dialogicality.

The idea that knowledge is constructed through dialogue goes back at least to the time of Socrates and has been reiterated by many others since then. Dialogicality refers to “the ways in which one speaker's concrete utterances come into contact with the utterances of another” (Wertsch, 1991: p. 54). Utterance refers to Bakhtin’s notion that meaning does not reside in words; rather, it resides in the ways in which words are used in particular contexts (Ball, 1999: p. 232). As Bakhtin (1986: p. 92) points out, “After all, our thought itself_-philosophical, scientific and artistic - is born in the process of interaction and struggle with others' thought”. According to 
Bakhtin, dialogicality refers to "all texts-written as well as spoken — that set up, in one way or other, relations between different voices” (Fairclough, 2003). For Bakhtin (1986: p. 69), an utterance is always and necessarily part of an ongoing dialogue in some sphere of activity. No one ever has the last word and equally, nobody breaks the silence of the universe. Thus, whenever we speak, we necessarily enter into an ongoing dialogue (Wells, 2007). While monologic discourse is usually associated with fixed transmission of unchanging ideas and status inequalities; dialogic discourse connotes social relationships of equal status, intellectual openness, and possibilities for critique and creative thought (O’Connor \& Michaels, 2007: p. 277).

Research suggests that when adults give children opportunities to become active participants during conversations, i.e. when the interactions are more dialogic, children show greater language gains (Whitehurst \& Lonigan, 1998). There is an increasing body of research that supports the view that talk is the key to learning (Lyle, 2008). This talk, i.e. dialogicality, introduces children to higher order thinking.

As can be seen in Table 1, Wells (2007) deploys three distinct binary oppositions in order to illustrate the differences between monologic and dialogic discourse, and claims that education requires both monologic and dialogic interaction. However, Wells essentially focuses on how dialogic discourse offers opportunities for learning of a kind not generally supported by monologic discourse.

In terms of classroom context, monologic and dialogic talk can be conceptualised as binary opposites and while monologic talk focuses power on the teacher, dialogic talk creates a space for multiple voices and discourses that challenge the asymmetrical power relations based on monologic practices (Lyle, 2008).

In Turkey, there are many studies examining Turkish maternal language (Küntay \& Slobin, 1995, 1996, 2001, 2002; Küntay \& Ahtam, 2004; Türkay, 2007; Cengiz, 2010, 2013; Cengiz \& Çakır, 2012a, 2015); however very little research examined the properties of paternal language (e.g. Cengiz \& Çakır, 2012b, 2016). Studies on fathers in Turkey usually focused on fathers' attitude towards child care, perceptions of their fathering roles and their participation levels in child care (e.g. Kuzucu, 2011; Taşkın, 2011; Zeybekoğlu, 2013). There is almost no research comparing maternal and paternal language use compared to the number of studies in other countries. The purpose of the present study is therefore to compare mother and father language input with their preschoolers and focus on the link between parents' SES and their dialogicality in the context of toy play.

To our knowledge, the relation between socioeconomic status, dialogicality and Turkish parents' language use has not yet been investigated. Although there are some limitations, this is the first study in Turkey comparing maternal and paternal child-directed speech and the first attempt to analyze Turkish parents' language input in relation to dialogicality. Thus, within the framework outlined so far, this study aims to provide an overview of linguistic development in the preschool years with a particular focus on parents' language input and their dialogicality. It tries to build upon the previous research on parents' language input and also extend the examination of the relation between SES and parents' dialogicality in the context of toy play. The following research question guides this study:

Do the parents' interaction styles differentiate in terms of dialogicality depending on their SES; thus, which children are encouraged more (by their parents) to become active speakers before they start their formal education?

\section{Method}

\subsection{Participants}

Ten fathers, ten mothers and their five-year old preschoolers participated in this study. Families were married, with both parents living in the home. They all lived in İzmir and were native Turkish speakers. Table 2 and Table 3 present and overview of the characteristics of the participants. Table 2 provides demographic information

Table 1. Two functions of discourse: monologic and dialogic

\begin{tabular}{|c|c|c|}
\hline & Monologic & Dialogic \\
\hline Bakhtin (1986) & Utterance as “authoritative” (meaning is fixed) & $\begin{array}{l}\text { Utterance as "internally persuasive" } \\
\text { (meaning is negotiable) }\end{array}$ \\
\hline Lotman (1988) & $\begin{array}{l}\text { Text as transmission or “monologic” device } \\
\text { (function: creates common memory for group) }\end{array}$ & $\begin{array}{l}\text { Text as "thinking device" } \\
\text { (function: generates new meanings) }\end{array}$ \\
\hline Tomasello (1999) & $\begin{array}{l}\text { Cultural practices function as social transmission } \\
\text { (ratchet effect, so cultural learning is maintained) }\end{array}$ & $\begin{array}{l}\text { Cultural practices function } \\
\text { to support creative invention }\end{array}$ \\
\hline
\end{tabular}

O’Connor \& Michaels (2007: p. 276). 
Table 2. Demographic characteristics of mothers

\begin{tabular}{|c|c|c|c|c|c|}
\hline \multicolumn{2}{|l|}{ Mothers } & Age & Mother's education & Mother's employment & Family monthly income \\
\hline \multirow{5}{*}{ High SES } & 1 & 33 & Master's degree & instructor & more than $3000 \mathrm{TL}$ (\$1050) \\
\hline & 2 & 34 & Master's degree & instructor & more than $3000 \mathrm{TL}$ (\$1050) \\
\hline & 3 & 34 & College graduate & instructor & more than $3000 \mathrm{TL}$ (\$1050) \\
\hline & 4 & 35 & College graduate & instructor & more than $3000 \mathrm{TL}$ (\$1050) \\
\hline & 5 & 36 & Master's degree & food engineer & more than 3000 TL (\$1050) \\
\hline \multirow{5}{*}{ Low SES } & 1 & 30 & Primary school graduate & housewife & less than $1000 \mathrm{TL}(\$ 350)$ \\
\hline & 2 & 32 & Primary school graduate & housewife & less than $1000 \mathrm{TL}(\$ 350)$ \\
\hline & 3 & 36 & Primary school graduate & housewife & less than $1000 \mathrm{TL}$ (\$350) \\
\hline & 4 & 39 & Secondary school graduate & housewife & less than $1000 \mathrm{TL}(\$ 350)$ \\
\hline & 5 & 40 & Primary school graduate & housewife & less than 1000 TL (\$350) \\
\hline
\end{tabular}

Table 3. Demographic characteristics of fathers

\begin{tabular}{|c|c|c|c|c|c|}
\hline \multicolumn{2}{|c|}{ Fathers } & \multirow{2}{*}{$\begin{array}{l}\text { Age } \\
34\end{array}$} & \multirow{2}{*}{$\begin{array}{l}\text { Father's education } \\
\text { College graduate }\end{array}$} & \multirow{2}{*}{$\begin{array}{c}\text { Father's employment } \\
\text { businessman }\end{array}$} & \multirow{2}{*}{$\begin{array}{c}\text { Family monthly income } \\
\text { more than } 3000 \text { TL (\$1050) }\end{array}$} \\
\hline \multirow{5}{*}{ High SES } & 1 & & & & \\
\hline & 2 & 34 & College graduate & bank employer & more than $3000 \mathrm{TL}(\$ 1050)$ \\
\hline & 3 & 34 & College graduate & instructor & more than $3000 \mathrm{TL}(\$ 1050)$ \\
\hline & 4 & 35 & $\mathrm{PhD}$ & Assist. Prof. & more than $3000 \mathrm{TL}(\$ 1050)$ \\
\hline & 5 & 36 & Master’s degree & engineer & more than 3000 TL (\$1050) \\
\hline \multirow{5}{*}{ Low SES } & 1 & 29 & Primary school graduate & worker & less than 1000 TL (\$350) \\
\hline & 2 & 32 & Primary school graduate & worker & less than 1000 TL (\$350) \\
\hline & 3 & 38 & Primary school graduate & self-employed & less than 1000 TL (\$350) \\
\hline & 4 & 48 & Secondary school graduate & self-employed & less than 1000 TL (\$350) \\
\hline & 5 & 54 & Secondary school graduate & TV repairman & less than 1000 TL (\$350) \\
\hline
\end{tabular}

on the mothers and Table 3 on the fathers contributing to this study. Low SES families had only a primary or secondary school education, and lived in suburban areas, whereas high SES families had completed four years of college or received a master's degree/ $\mathrm{PhD}$, and lived in more affluent districts of İzmir. All children attended nursery schools in their neighborhoods on weekdays.

As illustrated in Table 2, mother participants ranged in age from 30 to 40 years, with a mean of 34.9 years. The average age of high SES mothers was 34.4 and that of low SES mothers was 35.4.

As shown in Table 3, the father participants ranged in age from 29 to 54 years, with a mean of 37.4 years. The average age of high SES fathers was 34.6 and that of low SES fathers was 40.2. While low SES fathers had only a primary or secondary school education, high SES fathers had completed four years of college $(n=3)$ or received a master's $(n=1)$ or doctoral degree $(n=1)$. The fathers were employed outside of the home.

\subsection{Data Collection Procedure}

Participants were selected by means of purposive and snowball sampling methods. The reason for the small number of participants is that fathers had little or no incentive to attend, or were not available due to their working hours. Difficulties in recruitment of fathers were also caused by suspicion of a project on testing intelligence. Therefore, mothers were enlisted to encourage their partners to participate. Mothers' encouragement and information on the study helped to ensure father participation. The participation in the study was voluntary and all 20 
participants provided an informed consent prior to the study. After obtaining the participants' consent to contribute to the research, the families were visited at home by the researcher.

Before the observational session, each mother and father was interviewed regarding her/his education, age and employment. The parents' gender, age, education and monthly income were recorded. After the interview process, each mother-child dyad was invited into a separate room. Some toys were given and a picture where there was a bridge from building blocks was shown to the mother-child dyads. The toys used in this context were building blocks with a set of wooden blocks. They had different colors and shapes and contained a little bell, ramps and glass marbles. They were told to use the toy blocks either to build what they saw in the picture or that they were free to construct whatever they wanted.

Mothers were instructed to play with their children for about 15 - 20 minutes. The mother-child dyads sat on the floor during the play session. The researcher placed two voice recorders on the floor and was not present in the room during the recording in order to make the mothers and children feel comfortable. Recording started when they had settled in the room, which was one minute after they came into the room.

After the mothers played with their children, the fathers repeated the same procedure. Although they were playing with the same toys for the second time, the children were very interested in the toys and wanted to play again with their fathers.

\subsection{Data Analysis}

All mothers, fathers and their five-year old children showed an interest in the interactive toy play session. Each interaction lasted between 06:00 and 36:00 minutes $(M=15: 00 \mathrm{~min}$.). These interactions were taped and then transcribed. The unit of transcription was an utterance, so the speech of parents and children was coded as utterances. Two or more independent clauses occurring within the same conversational turn were considered as separate utterances. An utterance is defined as a conversational turn that contains one or more syntactic units and it is usually preceded and followed by a pause (Huttenlocher et al., 2010; Rowe, 2012). The utterances were then coded as exchanges. An exchange is the minimal interactive unit and involves the negotiation of a single piece of information (Stenström, 1994). Exchanges are independently observable entities. Each exchange was ascribed to the corresponding type of pattern; that is, each exchange was coded as an II, an IR or an IRF pattern. Sinclair \& Coulthard (1975) developed a model of classroom discourse. They found a structure of three-part exchanges in the traditional school classroom: Initiation, Response, and Feedback, known as IRF. According to them, the following is the typical classroom discourse sequences:

$\mathrm{T}$ : What's the capital of France? (Initiation)

S: Paris. (Response)

T: Yes, Paris. That's right. (Feedback)

These three moves, the teacher's initiation, the student's response and the teacher's feedback, consist of an exchange. IRF pattern, also called the triadic dialogue, is the dominant form of interaction in a classroom setting. The model proposed to show how interaction in the classroom takes place by taking a linguistic and functional look at discourse. The model was originally developed through the application of transcripts taken from classroom settings in the 1970's. However, these settings were primarily teacher-centered which has led to some criticisms of the model. Nevertheless, IRF pattern has been widely accepted by the researchers as a useful category to analyze classroom discourse, and it remains a relatively powerful model that allows us to objectively evaluate communication that occurs in the classroom (Liu \& Le, 2012; Nicholson, 2014).

Focusing on the interaction between parents and their children, this study examined the exchange patterns of parents and their preschoolers, and tried to reveal the dominant interactional patterns among families coming from different socioeconomic backgrounds. Thus, the pattern was coded as an IRF where the mother or father made the initiation and feedback/follow-up moves while the child responded; the pattern was coded as an IR where the mother or father made the initiation, the child responded and there was no feedback/follow-up move, and lastly, the pattern was coded as an II where the parents made the initiation and when there was no response from the child, they continued with another initiation, so there was no speaker shift, thus no dialogicality. The use of IR pattern shows that the discourse was dialogic, at least there was a speaker shift, thus a space for children's voices. The use of IRF, that is when there occurs an F move, the discourse was again dialogic and the F move has a great importance; research has shown that children always need some kind of feedback and this is the F move that supports and encourages children. 
Since the sample size of the study was small, a nonparametric test, two-independent-sample test, Mann Whitney U was applied using IBM SPSS statistical packages (version 21.0). The critical alpha value was set at 0.05 for this investigation. Significant $\mathrm{p}$-values $(p<.05)$ are highlighted in grey in tables displaying scores.

\section{Results}

This study aimed to examine the link between mothers' and father's socioeconomic status and their language use with regard to their dialogicality. Figure 1 presents the raw numbers on total utterances, IR, II and IRF moves of mothers and fathers.

As seen in Figure 1, the analyses on the number of utterances revealed that fathers produced more utterances than mothers while playing with their children. In other words, fathers spoke to their children much more than mothers did. The IRF move is used extensively by high SES mothers and fathers. The results also revealed that the II structure was preferred by low SES mothers and fathers. The scores on the IR structure demonstrated similar results.

Table 4 presents the descriptive statistics of total utterances produced by mothers and fathers during toy play.

As shown in Table 4, high SES mothers' total utterance score was $M d n=221$ while low SES mothers' score was $M d n=128$. The difference between these two groups was not significant ( $p$-value $=.175)$. However, the difference between high SES fathers $(\mathrm{Mdn}=300)$ and low SES fathers $(\mathrm{Mdn}=212)$ was statistically significant $(p$-value $=.047)$.

As to whether there was a significant difference between high SES mothers (Mdn = 221) and high SES fathers $(\mathrm{Mdn}=300)$ in terms of their scores on the total utterances, Mann Whitney $\mathrm{U}$ results $(p=.175>.05)$ indicated that there was no significant difference between these two groups. There was also no difference between low SES mothers $(\mathrm{Mdn}=128)$ and low SES fathers $(\mathrm{Mdn}=212)$ in total utterances $(p=.753>.05)$.

Table 5 illustrates the descriptive statistics of the IR (Initiation-Response) moves of mothers and fathers during free play.

As presented in Table 5, high SES mothers' score on the IR pattern was Mdn $=9$ and low SES mothers' score was $M d n=3$. The difference between mothers was not significant $(p$-value $=.175)$. The difference between

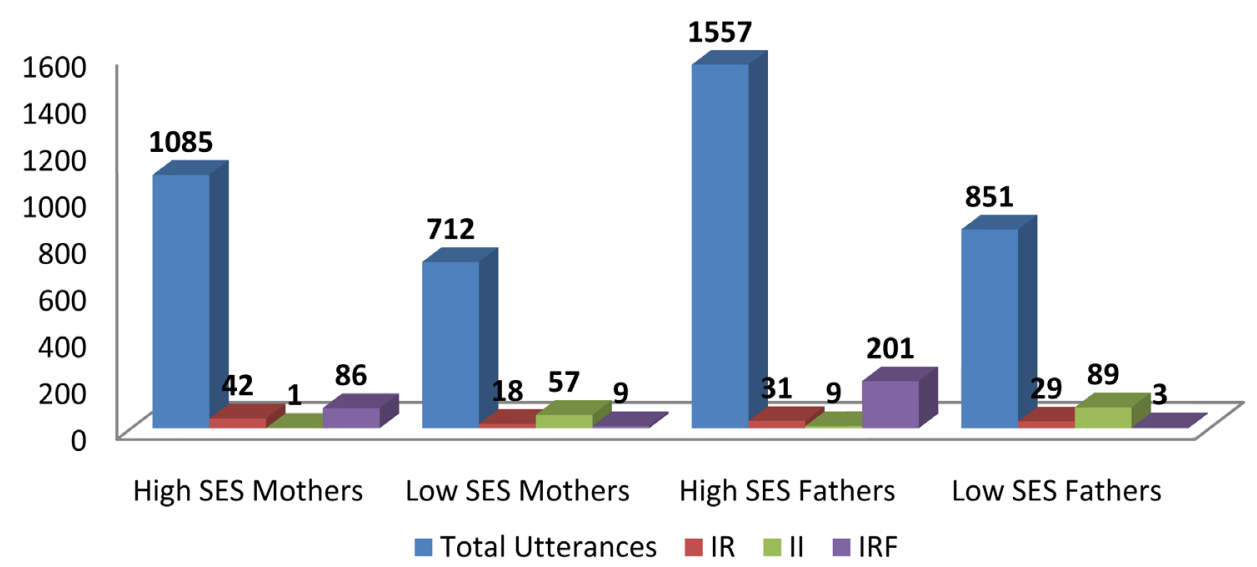

Figure 1. Raw numbers of mothers' and fathers' total utterances, IR, II and IRF moves.

Table 4. Descriptive statistics of mothers' and fathers' total utterances

\begin{tabular}{|c|c|c|c|c|c|c|c|c|}
\hline Group & $\mathrm{N}$ & Minimum & Maximum & Mean & Median & $\mathrm{SD}$ & Variance & Sum \\
\hline High SES Mother & 5 & 70.0 & 308.0 & 217.000 & 221.000 & 91.7987 & 8427.000 & 1085.0 \\
\hline Low SES Mother & 5 & 74.0 & 219.0 & 142.400 & 128.000 & 59.6180 & 3554.300 & 712.0 \\
\hline High SES Father & 5 & 89.0 & 563.0 & 311.400 & 300.000 & 168.3487 & 28341.300 & 1557.0 \\
\hline Low SES Father & 5 & 64.0 & 286.0 & 170.200 & 212.000 & 100.8920 & 10179.200 & 851.0 \\
\hline Total & 20 & 64.0 & 563.0 & 210.250 & 215.500 & 122.3519 & 14969.987 & 4205.0 \\
\hline
\end{tabular}


Table 5. Descriptive statistics on mothers’ and fathers’ IR (Initiation-Response) moves

\begin{tabular}{cccccccccc}
\hline Group & N & Minimum & Maximum & Mean & Median & SD & Variance & Sum \\
\hline High SES Mother & 5 & 0.0 & 15.0 & 8.400 & 9.000 & 5.5498 & 30.800 & 42.0 \\
Low SES Mother & 5 & 1.0 & 8.0 & 3.600 & 3.000 & 2.7019 & 7.300 & 18.0 & \\
High SES Father & 5 & 5.0 & 8.0 & 6.200 & 6.000 & 1.3038 & 1.700 & 31.0 & \\
Low SES Father & 5 & 2.0 & 12.0 & 5.800 & 5.000 & 3.9623 & 15.700 & 29.0 \\
Total & 20 & 0.0 & 15.0 & 6.000 & 5.500 & 3.8389 & 14.737 & 120.0 \\
\hline
\end{tabular}

high SES fathers $(\operatorname{Mdn}=6)$ and low SES fathers $(\operatorname{Mdn}=5)$ was not statistically significant either ( $p$-value $=.525)$.

There was no significant differences between high SES mothers $(\mathrm{Mdn}=9)$ and high SES fathers $(\mathrm{Mdn}=6)$, and $(p=.207>.05)$, also between low SES mothers $(\mathrm{Mdn}=3)$ and low SES fathers $(\mathrm{Mdn}=5)$ in terms of IR structure use $(p=.344>.05)$.

Table 6 shows the descriptive statistics of the II (Initiation-Initiation) moves of mothers and fathers during play time.

Table 6 illustrates that high SES mothers' use of the II pattern was Mdn $=0$ while low SES mothers' score was $M d n=11$. The difference between high SES and low SES mothers was statistically significant $(p=.007$ $<$.05). Moreover, the difference between high SES fathers $(\mathrm{Mdn}=2)$ and low SES fathers $(\mathrm{Mdn}=17)$ was also statistically significant $(p=.009<.05)$. A significant difference was also found between high SES mothers $(\mathrm{Mdn}=0)$ and high SES fathers $(\mathrm{Mdn}=2)(p=.043<.05)$. However, the findings on low SES mothers $(\mathrm{Mdn}=$ $11)$ and low SES fathers $(\mathrm{Mdn}=17)$ did not reveal a significant score $(p=.530>.05)$.

Table 7 presents the descriptive statistics of the IRF (Initiation-Response-Follow Up) moves of mothers and fathers.

As for IRF pattern, a preliminary inspection of the median values showed a significant difference between the scores of high SES mothers $(\mathrm{Mdn}=14)$ and low SES mothers (Mdn $=1 ; p=.008<.05)$. There was also a significant difference between high SES fathers $(\mathrm{Mdn}=36)$ and low SES fathers $(\mathrm{Mdn}=0 ; p=.008<.05)$. Additionally, a significant difference was found between high SES mothers (Mdn = 14) and high SES fathers (Mdn = $36 ; p=.047<.05)$. No significant difference $(p=.100>.05)$ was observed between IRF moves of low SES mothers and fathers.

\section{Discussion}

This study aimed to compare maternal and paternal language use with a specific emphasis on their dialogicality. There was no significant difference between high SES and low SES mothers in terms of total utterance and IR moves, while significant difference was found on II and IRF moves. As for the high SES and low SES fathers, no significant difference was observed on IR moves; however the scores on total utterances, II and IRF moves revealed significant differences. In terms of gender, the comparison of low SES and high SES parents also demonstrated differences. No significant difference was found between high SES mothers and fathers on total utterances and IR moves, but the scores on II and IRF moves revealed a significant difference. The differences between low SES mothers and low SES fathers demonstrated no significant results on total utterances, IR, II and IRF moves.

Although the sample size was small, according to the findings, socioeconomic status of parents showed a difference in dialogicality, i.e. in the IR and IRF patterns, and also in the total amount of utterances. Since IRF consists of more multiple voices, it might be related with dialogic discourse, rather than monologic. Thus, families coming from high education and income produced more utterances and they tried to create more dialogic interactions with their preschoolers. They tended to give more chance to their children to talk during toy play interactions and encouraged their children to speak more before starting formal education. On the other hand, the power was more on the parents' in families coming from low SES, so there was more II patterns where only parents talked. As for the importance of the F move, children need guidance in building knowledge. Particular talk moves, such as feedback/follow-up, support children; it is for this reason that the importance of increasing the use of dialogic practices is emphasized. Classroom settings where there were many IRF patterns are accepted 
Table 6. Descriptive statistics on mothers’and fathers’ II (Initiation-Initiation) moves

\begin{tabular}{cccccccccc}
\hline Group & N & Minimum & Maximum & Mean & Median & SD & Variance & Sum \\
\hline High SES Mother & 5 & 0.0 & 1.0 & .200 & 0.000 & .4472 & .200 & 1.0 \\
Low SES Mother & 5 & 5.0 & 21.0 & 11.400 & 11.000 & 6.0249 & 36.300 & 57.0 & \\
High SES Father & 5 & 0.0 & 4.0 & 1.800 & 2.000 & 1.4832 & 2.200 & 9.0 & 1720 \\
Low SES Father & 5 & 7.0 & 39.0 & 17.800 & 17.000 & 12.8725 & 165.700 & 89.0 \\
Total & 20 & 0.0 & 39.0 & 7.800 & 4.500 & 9.8707 & 97.432 & 156.0 \\
\hline
\end{tabular}

Table 7. Descriptive statistics on mothers'and fathers’ IRF (Initiation-Response-Follow Up) moves

\begin{tabular}{ccccccccc}
\hline Group & N & Minimum & Maximum & Mean & Median & SD & Variance & Sum \\
\hline High SES Mother & 5 & 5.0 & 39.0 & 17.200 & 14.000 & 12.9692 & 168.200 & 86.0 \\
Low SES Mother & 5 & 1.0 & 4.0 & 1.800 & 1.000 & 1.3038 & 1.700 & 9.0 \\
High SES Father & 5 & 21.0 & 65.0 & 40.200 & 36.000 & 16.6943 & 278.700 & 201.0 \\
Low SES Father & 5 & 0.0 & 2.0 & .600 & 0.000 & .8944 & .800 & 3.0 \\
Total & 20 & 0.0 & 65.0 & 14.950 & 4.500 & 19.0635 & 363.418 & 299.0 \\
\hline
\end{tabular}

as teacher-centered, and they have come under criticisms; even sometimes IRF patterns have been charged with being monologic. However in our context, we accepted the IRF patterns dialogic. When compared to II patterns, where there are no speaker shift, IRF patterns can be accepted more dialogic. High SES families provide speaking opportunities for their children with the R moves, and they provide guidance with the F moves.

The findings of this study are consistent with previous findings. Heath (1983) and Ninio (1980) also found that parents from low SES talk much less to their children than high SES parents. According to Hoff, Laursen \& Tardif (2002), maternal language input to children changes depending on family SES; high SES mothers contributes more to child language development. Fish \& Pinkerman (2003) and Hoff-Ginsberg (1998) also observed that child-directed speech in high SES families contained richer vocabulary of object labels. Low SES mothers, on the other hand, talked less and used less varied vocabulary.

Several limitations of this study should be noted. First, this study is limited in that it examined parents' language use only in the context of toy play. Future research could include other activities such as book reading, picture reading, meal time etc. There is also a need for studies with an intervention program to raise parents' awareness on their contribution to child language development. Another limitation of this study was the non-homogeneity of mothers' and fathers' personal characteristics and the fact that the sample size $(n=20)$ was small. Future multidisciplinary and longitudinal studies are needed to investigate maternal and paternal language input and their effects in different contexts with a greater number of participants. Since this research was a cross-sectional study and the sample was not representative especially with regard to parents' personal characteristics, the parents cannot be generalized to the general population of parents. Thus, the results of this study should be interpreted with caution, and the limitations of the study should be borne in mind.

\section{Conclusions}

Most of our learning about the world we inhabit is through dialogue with others. The more parents give their children the opportunity to speak at home, the more children will be accustomed to speak at school. The development of ability to use school-based registers is crucially dependent on learners' experience. Thus, particularly "learning through conversation with a responsive adult" should occur more often at homes. Through dialogic discourse, children can have the opportunities of becoming active speakers and thinking critically.

The findings of this study may shed light on the fact that the characteristics of the child-directed speech is influenced both by the gender of caregivers and by the socioeconomic backgrounds of parents. The present study can be regarded as having extended the existing Turkish literature on parents' language use and their dialogicality. However, a larger group of participants is necessary to identify quantity and quality of language differences between parents. 


\section{Acknowledgements}

This study is the result of great effort on the part of many people. I thank all the mothers, fathers and their children who took part in this study. Without their cooperation, this study would not have been possible.

\section{References}

Bakhtin, M. M. (1986). Speech Genres and Other Late Essays. Austin: University of Texas Press.

Ball, A. F. (1999). Preservice Teachers' Perspectives on Literacy and Its Use in Urban Schools. A Vygotskian Perspective on Internal Activity and Teachers Change. In C. Lee, \& P. Smagorinsky (Eds.), Vygotskian Perspective on Literacy Research: Constructing Meaning through Collaborative Inquiry (pp. 314-359). Cambridge, UK: Cambridge University Press.

Cabrera, N. J., Shannon, J. D., \& Tamis-LeMonda, C. (2007). Fathers' İnfluence on Their Children's Cognitive and Emotional Development: From Toddlers to Pre-K. Applied Developmental Science, 11, 208-223. http://dx.doi.org/10.1080/10888690701762100

Cengiz, Ö., \& Çakır, H. (2015). An Investigation of Maternal Input within the Framework of Bloom's Taxonomy of Cognitive Domain. In Zeyrek, D., Sagın Simsek, Ç.,Atas, U., \& Rehbein, J. (Eds.) Ankara Papers in Turkish and Turkic Linguistics (pp. 225-235). Wiesbaden: Harrassowitz Verlag.

Cengiz, Ö. (2010). Türk Annelerin Çocuklarına Kitap Okurken Kullandıkları Dilsel Kodlar ve Etkileşim Biçemi. (The Linguistic Codes and the Types of Verbal Interactions of Turkish Mothers in the Context of Shared Book Reading). Unpublished Dissertation. İzmir: Dokuz Eylül University.

Cengiz, Ö. (2013). The Language Use of Turkish Mothers in the Context of Shared Book Reading. Journal of Faculty of Letters, 30, 97-114.

Cengiz, Ö., \& Çakır, H. (2012a). Okulöncesi Çocuklarda Dilbilgisel Eğretileme Kullanımının Ortaya Çıkış Sürecinde Annelerinin Etkisi (The Effects of Mothers in the Emergence of Grammatical Metaphor Use in Preschoolers). Journal of Linguistic Research, 2012, 21-39.

Cengiz, Ö., \& Çakır, H. (2012b). A Study of Fathers' Language Input with Regard to Bloom's Taxonomy of Cognitive Domain. Proceedings Book of International Symposium on Language and Communication: Research Trends and Challenges (pp. 565-578). Erzurum: Mega Press.

Cengiz, Ö., \& Çakır, H. (2016). Turkish Fathers’ Language Use in the Context of Toy Play. European Scientific Journal, 12, 430-447.

Duursma, E. (2014). The Effects of Fathers' and Mothers' Reading to Their Children on Language Outcomes of Children Participating in Early Head Start in the United States. Fathering, 12, 283-302.

Duursma, E., Pan, B. A., \& Raikes, H. (2008). Predictors and Outcomes of Low-Income Fathers' Reading with Their Toddlers. Early Childhood Research Quarterly, 23, 351-365. http://dx.doi.org/10.1016/j.ecresq.2008.06.001

Fairclough, N. (2003). Analysing Discourse: Textual Analysis for Social Research. New York: Routledge.

Fernald, A., Taeschner, T., Dunn, J., \& Papousek, M. (1989). A Cross-Language Study of Prosodic Modification in Mothers' and Fathers' Speech to Preverbal Infants. Journal of Child Language, 19, 477-501. http://dx.doi.org/10.1017/S0305000900010679

Fish, M., \& Pinkerman, B. (2003). Language Skills in Low-SES Rural Appalachian Children: Normative Development and İndividual Differences, İnfancy to Preschool. Applied Developmental Psychology, 23, 539-565. http://dx.doi.org/10.1016/S0193-3973(02)00141-7

Golinkoff, R. M., \& Ames, G. J. (1979). A Comparison of Fathers’ and Mothers' Speech with Their Young Children. Child Development, 50, 28-32. http://dx.doi.org/10.2307/1129037

Hart. B., \& Risley, T. (1995). Meaningful Differences in the Everyday Experience of Young American Children. Baltimore, MD: Paul H. Brookes Publishing Co., Inc.

Heath, S. B. (1983). Ways with Words: Language, Life, and Work in Communities and Classrooms. Cambridge: Cambridge University Press.

Hladik, E. G., \& Edwards, H. T. (1984). A Comparative Analysis of Mother-Father Speech in the Naturalistic Home Environment. Journal ofPsycholinguistic Research, 13, 321-332. http://dx.doi.org/10.1007/BF01068149

Hoff, E. (2003). The Specificity of Environmental Influence: Socioeconomic Status Affects Early Vocabulary Development via Maternal Speech. Child Development, 74, 1368-1378. http://dx.doi.org/10.1111/1467-8624.00612

Hoff, E., Laursen, B., \& Tardif, T. (2002). Socioeconomic Status and Parenting. In M. H. Bornstein (Ed.), Handbook of Parenting (pp. 231-252). Mahwah, NJ: Erlbaum.

Hoff-Ginsberg, E. (1998). The Relation of Birth Order and Socioeconomic Status to Children's Language Development. Applied Psycholingistics, 19, 603-629. http://dx.doi.org/10.1017/S0142716400010389 
Huttenlocher, J., Waterfall, H., Vasilyeva, M., Vevea, J., \& Hedges, L. V. (2010). Sources of Variability in Children’s Language Growth. Cognitive Psychology, 61, 343-365. http://dx.doi.org/10.1016/j.cogpsych.2010.08.002

Kavanaugh, R. D., \& Jirkovsky, A. M. (1982). Parental Speech to Young Children: A Longitudinal Analysis. Merrill-Palmer Quarterly, 28, 297-311.

Küntay, A. C., \& Ahtam, B. (2004). Annelerin çocukalarıyla geçmiş hakkındaki konuşmalarının Anne eğitim düzeyiyle ilişkisi (Effect of Maternal Education on Turkish Mothers' Styles of Reminiscing with Their Children). Turkish Journal of Psychology, 19, 19-31.

Küntay, A. C., \& Slobin, D. I. (2002). Putting Interaction Back into Child Language: Examples from Turkish. Psychology of Language and Communication, 6, 5-14.

Küntay, A., \& Slobin, D. I. (1995). Nouns and Verbs in Turkish Child Directed Speech. In D. MacLaughlin, \& S. McEwen (Eds.), Proceedings of the 19th Annual Boston University Conference on Language Development 1 (pp. 323-334). Somerville, MA: Cascadilla Press.

Küntay, A., \& Slobin, D. I. (1996). Listening to a Turkish Mother: Some Puzzles for Acquisition. In D. I. Slobin, J. Gerhardt, A. Kyratzis, \& J. Guo (Ed.), Social Interaction, Social Context, and Language: Essays in Honor of Susan Ervin-Tripp. (pp. 265-286). Hillsdale, NJ: Lawrence Erlbaum Associates.

Küntay, A., \& Slobin, D. I. (2001). Discourse Behavior of Lexical Categories in Turkish Child-Directed Speech: Nouns vs. Verbs. In M. Almgren, A. Barreña, M. Ezeizabarrena, I. Idiazabal, \& B. MacWhinney (Eds.), Research on Child Language Acquisition: Proceedings for the 8th Conference of the International Association for the Study of Child Language (pp. 928-946). Somerville, MA: Cascadilla Press.

Kuzucu, Y. (2011). Değişen babalık rolü ve çocuk gelişimine etkisi (The Changing Role of Fathers and Its Impact on Child Development). Türk Psikolojik Danışma ve Rehberlik Dergisi, 4, 79-91.

Leaper, C., Anderson, K. J., \& Sanders, P. (1998). Moderators of Gender Effects on Parents’ Talk to Their Children: A Meta-Analysis. Developmental Psychology, 34, 3-27. http://dx.doi.org/10.1037/0012-1649.34.1.3

Liu, J., \& Le, T. (2012). A Case Study on College English Classroom Discourse. International Journal of Innovative Interdisciplinary Research, 2, 1-10.

Lotman, Y. M. (1988). Text within a Text. Soviet Psychology, 26, 32-51. http://dx.doi.org/10.2753/rpo1061-0405260332

Lyle, S. (2008). Dialogic Teaching: Discussing Theoretical Contexts and Reviewing Evidence from Classroom Practice. Language and Education, 22, 222-240. http://dx.doi.org/10.1080/09500780802152499

McCabe, A., \& Peterson, C. (1991). Getting the Story: Parental Styles of Narrative Elicitation and Developing Narrative Skills. In A. McCabe, \& C. Petarson (Eds.), Developing Narrative Structure (pp. 217-253). Hillsdale, NJ: Lawrence Erlbaum.

McLaughlin, B., White, D., McDevitt, T., \& Raskin, R. (1983). Mothers' and Fathers' Speech to Their Young Children: Similar or Different? Journal of Child Language, 10, 245-252. http://dx.doi.org/10.1017/S0305000900005286

McRoberts, G. W., \& Best, C. T. (1997). Accommodation in Mean $\mathrm{f}_{0}$ during Mother-Infant and Father-Infant Vocal Interactions: A Longitudinal Case Study. Journal of Child Language, 24, 719-736.

http://dx.doi.org/10.1017/S030500099700322X

Nicholson, S. J. (2014). An Impetus for Change: Classroom Analysis Using Sinclair and Coulthard's Model of Spoken Discourse. International Journal of Linguistics, 6, 199-219. http://dx.doi.org/10.5296/ijl.v6i2.5464

Ninio, A. (1980). Picture-Book Reading in Mother-Infant Dyads Belonging to Two Subgroups in Israel. Child Development, 51, 587-590. http://dx.doi.org/10.2307/1129299

O’Brien, M., \& Nagle, K. J. (1987). Parents' Speech to Toddlers: The Effect of Play Context. Journal of Child Language, 14, 269-279. http://dx.doi.org/10.1017/S0305000900012927

O’Connor, C. \& Michaels, S. (2007). When Is Dialogue “Dialogic”? Human Development, 50, 275-285. http://dx.doi.org/10.1159/000106415

Pancsofar, N., \& Vernon-Feagans, L. (2006). Mother and Father Language Input to Young Children: Contributions to Later Language Development. Journal of Applied Developmental Psychology, 27, 571-587. http://dx.doi.org/10.1016/j.appdev.2006.08.003

Pancsofar, N., \& Vernon-Feagans, L. (2010). Fathers’ Early Contributions to Children's Language Development in Families from Low-Income Rural Communities. Early Childhood Research Quarterly, 25, 450-463. http://dx.doi.org/10.1016/j.ecresq.2010.02.001

Pancsofar, N., Vernon-Feagans, L., Odom, E. C., \& The Family Life Project Investigators (2013). Work Characteristics and Fathers' Vocabulary to Infants in African American Families. Journal of Applied Developmental Psychology, 34, $73-81$. http://dx.doi.org/10.1016/j.appdev.2012.11.005

Peterson, C., \& McCabe, A. (1992). Parental Styles of Narrative Elicitation: Effect on Children’s Narrative Structure and Content. First Language, 12, 299-321. http://dx.doi.org/10.1177/014272379201203606 
Raikes, H., Pan, B. A., Luze, G., Tamis-LeMonda, C.S., Brooks-Gunn, J. et al. (2006). Mother-Child Bookreading in Low-İncome Families: Correlates and Outcomes during the First Three Years of Life. Child Development, 77, 924-953. http://dx.doi.org/10.1111/j.1467-8624.2006.00911.x

Rondal, J. A. (1980). Fathers' and Mothers' Speech in Early Language Development. Journal of Child Language, 7, $353-369$. http://dx.doi.org/10.1017/S0305000900002671

Rowe, M. L. (2008). Child-Directed Speech: Relation to Socioeconomic Status, Knowledge of Child Development and Child Vocabulary Skill. Child Language, 35, 185-205. http://dx.doi.org/10.1017/S0305000907008343

Rowe, M. L. (2012). A Longitudinal Investigation of the Role of Quantity and Quality of Child Directed Speech in Vocabulary Development. Child Development, 83, 1762-1774. http://dx.doi.org/10.1111/j.1467-8624.2012.01805.x

Sinclair, J., \& Coulthard, R. M. (1975). Towards an Analysis of Discourse. Oxford: Oxford University Press.

Stenström, A. (1994). An Introduction to Spoken Interaction. London \& New York: Longman.

Tamis-LeMonda, C. S., Shannon, J.D., Cabrera, N., \& Lamb, M. (2004). Fathers and Mothers at Play with Their 2- and 3Year-Olds. Contribution to Language and Cognitive Development. Child Development, 75, 1806-1820. http://dx.doi.org/10.1111/j.1467-8624.2004.00818.x

Taşkın N. (2011). Çocukların gelişiminde katkıları unutulanlar: Babalar. Eğitim Birsen, 7, 43-47.

Tomasello, M. (1999). The Cultural Origins of Human Cognition. Cambridge: Harvard University Press.

Türkay, F. (2007). Türk Annelerin ad/eylem kullanımlarının Bağlam etmeniyle ilişkisi. In 21. Dilbilim Kurultayı Bildirileri (pp. 273-276). Mersin: Mersin Üniversitesi Yayınları.

Wells, G. (2007). Semiotic Mediation, Dialogue and the Construction of Knowledge. Human Development, 50, $244-274$. http://dx.doi.org/10.1159/000106414

Wertsch, J. V. (1991). Voices of the Mind: A Sociocultural Approach to Mediated Action. Hemel Hempstead: Harvester Wheatsheaf.

Whitehurst, G. J., \& Lonigan, C. J. (1998). Child Development and Emergent Literacy. Child Development, 69, 848-872. http://dx.doi.org/10.1111/j.1467-8624.1998.tb06247.x

Zeybekoğlu, Ö. (2013). Günümüz erkeklerin gözünde babalık ve aile (Contemporary Fatherhood and the Family from the Male Perspectives). Mediterranean Journal of Humanities, III, 297-328. http://dx.doi.org/10.13114/MJH/201322486 